\title{
介護老人保健施設に勤務する介護職員による 日常生活介助の実態調查
} 一ベッドから車椅子への移乗介助に対する学習理論からの検討一

\section{Survey of Assisting Methods for ADL by Care Workers Work in Care Health Center for the Elderly: Investigation by Learning Theory about Assisting Transfer from Bed to Wheel Chair}

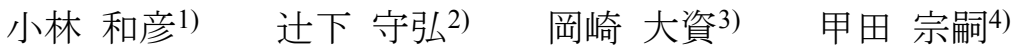

\author{
KAZUhiko KOBAYASHI ${ }^{1)}$, Morihiro TSUJISHITA ${ }^{2)}$, DAISUKe OKAZAKI ${ }^{3)}$, Munetsugu KODA ${ }^{4}$ \\ 1) Department of Health Science, Tsukuba College of Technology: 4-12-7 Kasuga, Tsukuba City, Ibaraki 305-8521, Japan. \\ TEL +81 029-858-9553 \\ 2) Department of Nursing and Rehabilitation, Kounan Women's University \\ 3) Gumma Paz College Faculty of Health Science School of Physical Therapy \\ 4) Department of Rehabilitation, Hiroshima City Rehabilitation Center
}

Rigakuryoho Kagaku 25(5): 825-830, 2010. Submitted Mar. 13, 2010. Accepted Apr. 29, 2010.

ABSTRACT: [Purpose] The purpose of this survey was to investigate how care workers assist institutionalised disabled elderly in care health centers for the elderly from the viewpoint of learning theory. [Subjects] Participants in this study were 29 care workers and 3 institutionalised elderly who are cared by them. [Methods] We recorded and classified, what kind of assistance carers used, whether they were able to wait or not, and what kind of responses they made to each of the elderly's behavior, and then we calculated the total number of them. [Results] The results revealed that $87 \%$ "totally assisted", $4 \%$ of the time carers were "not able to wait", $82 \%$ of the time carers gave "no response", $3 \%$ of the time carers gave "praise" for elderly's behavior, and $15 \%$ of the time assistance was given in the middle of elderly's behavior. [Conclusion] The results of this survey suggest that carers' assistance increased the elderly's dependent behavior and decreased independent behavior from the viewpoint of learning theory.

Key words: care health center for the elderly, assisting transfer, learning theory

要旨：〔目的〕介護老人保健施設に勤務する介護職員が，日頃のどのような移乗介助を行っているかを調査し，そ の介助方法が対象者の課題遂行行動に与える影響について行動法則に照らして検討した。[対象〕 3 箇所の施設の介 護職員 29 名と入所者 3 名とした。〔方法〕入所者がベッドから車椅子へ移乗する機会を利用して,「介護職員が行っ た介助」および「入所者の移乗課題遂行後における介護職員の対応」の種類とその回数, 「介護職員がそれら介助 施行前に入所者の行動生起を “待機” したか否か」を約 3 週間にわたり調査した。〔結果〕総回数 260 回の介助の 87 \%で直接 “全介助”が行われ，“全介助”が行われる前に“部分的身体介助”もしくは “声がけ”が行われたのは 各々 $8 \%$ と $5 \%$, “待機”が行われたのは総介助回数の $4 \%$ であった。また, 介助により入所者が移乗課題を遂行し た後の介護職員の対応は $82 \%$ が入所者に対し “無反応”で，“賞賛”や“承認”が与えられたのは $3 \%$ 㐫り，15\% の “中途介助”が行われていた。〔結語〕入所者の依存行動を増加させ，自立行動を減少させる介助が行われてい る可能性が高いことが示唆された。

キーワード : 介護老人保健施設, 移乗介助, 学習理論

1) 筑波技術大学 保健科学部保健学科：茨城県つくば市春日4-12-7（†305-8521）TEL 029-858-9553

2) 甲南女子大学 看護リハビリテーション学部理学療法学科 3) 群馬パース大学 保健科学部保健学科

4) 広島市総合リハビリテーションセンター リハビリテーション科

受付日 2010年3月13日 受理日 2010年4月29日 


\section{I. 緒 言}

わが国の介護老人保健施設における主旨から, 不活 動による廃用性の機能低下が危惧される高齢者に対し ては，医学的なリハビリテーションとともに日常生活 において依存的な行動を減少させ，自立的な行動を増 加させることを意図した行動論的な援助が重要である と考えられる。

Baltes $ら^{1-3)}$ が行った高齢者を取り巻く社会的環境要 因に関する一連の調查研究によると，高齢者ケアに携 わる多くの介護職員が彼らに日常生活を遂行する能力 がないと推測し，たとえ依頼や必要性がなくとも援助 してしまうという状況が多くの高齢者施設において認 められるという。そして, このような過剩な対応や援 助が高齢者を “学習性の依存 (learned dependency)” に 導き，その結果 “不活動”を引き起こし日常生活能力 を低下させていることを指摘している。また, 博野4) 介護職員が認知症を有する高齢者の日常生活能力の障 害と必要な介助方法を理解していない場合, 介護対象 である高齢障害者の本来の能力を見極められず, 日常 生活における活動の必要以上を介助してしまうことで 日常生活能力を低下させてしまうことがあるとしてい る。これらの指摘は, 高齢者自身が能力的に十分可能 な日常生活のスキルを, 彼らを取り巻く人的環境が代 行してしまうことで依存的な行動の増加や自立的な行 動の減少を引き起こし, 廃用性の機能低下を促進させ ていることに対する警鐘といえる。しかしながら，介 護老人保健施設に勤務する介護職員が，彼らが日頃介 助する高齢障害者に対し具体的にどのような介助や対 応を行っているかはあまり調査がなされていないのが 現状である。

そこで, 本調查においては理学療法士が介護老人保 健施設入所者の身体機能の維持・向上を担う専門職で あり, 介護職員の日常生活介助の実態を把握した上で 適切な介助指導を行うという重要な責務を有している と考えられることから, 日頃彼らが介助する高齢障害 者のベッドから車椅子への移乗課題に対し “声がけ”, “部分的身体介助”や“全介助”などの介助をどのよう に用いているか，そして入所者が課題を遂行した場合 どのような対応を行っているかを調查し, それら介助 や対応の仕方が対象者の移乗課題遂行行動に与える影 響の可能性について “オペラント条件付け理論”の代 表的な行動法則5-7)に照らして検討した。

\section{II. 対象と方法}

1. 対象

対象介護職員は茨城県内における3力所の介護老人 保健施設に勤務し, 調查依頼に承諾が得られた 29 名 (A 施設 21 名・B 施設 5 名・C施設 3 名）で，彼らが日頃介 助する高齢障害者 3 名を対象入所者とした。入所者 $\mathrm{D}$ （A施設入所）は糖尿病による入院後, 長期臥床により ほぼ寝たきりとなった 74 歳の男性で, その後, 病院で のリハビリテーションにより身体機能の向上が見られ たものの全身性に廃用性の筋力低下を認め, 行動意欲 に乏しく施設内に打ける移動・移乗において車椅子レ ベルにてほぼ全介助の状況となっている。認知的な問 題は特に認められず, 長谷川式簡易認知症検查（HDSR）は23点で, コミュニケーションは良好であった。入 所者 $\mathrm{E}$ (B施設入所) は脳梗塞後遺症により左片麻瘒と なった78歳の女性で, 麻瘏は中等度, 認知症 (HDS-R; 16 点）によりコミュニケーションは困難だが，簡単な 指示は理解できる。右下肢（健側）および体幹に軽度 の廃用性筋力低下を認め, 行動意欲にそしく施設内生 活は車椅子使用によりほぼ全介助で寝たきりに近い状 況であった。また, 入所者 $\mathrm{F}$ (C施設入所）は脳梗塞に より左片麻痺となった 74 歳の男性で, 麻瘏は軽度だが, 認知症疑い（HDS-R；21 点）および難聴のためコミュ ニケーションはやや困難（簡単なやりとりは理解でき る)。体幹・両下肢に廃用性の筋力低下があり, 施設内 生活は車椅子使用によりほぼ全介助の状況であった。

3力所の施設の施設長にはあらかじめ調查の目的およ び内容を説明し同意を得た。各施設における介護職員 には施設長より研究主旨の説明と協力依頼を行っても らい, 協力の意志のあった介護職員すべてを調查協力 者として選出した。また, 各施設における3 名の入所者 に対しても, 調查目的などをわかりやすく説明するこ とで同意を得ることができた。また，各入所者の家族 に対しては看護師長を通して同意を得てもらった。

\section{2. 方法}

入所者のベッドから車椅子への移乗能力については, Mathews ( $^{8)}$ が認知症を有する高齢者施設入所者の更衣 や整容などの介助評価に用いたSLP (System of Least Prompts）による評価基準を筆者ら ${ }^{9)}$ にり移乗介助評 価用に修正されたものを用いた（表1)。ここでいうSLP とは, 対象者に対し “身体介助” “全介助” などの援 助力の強い（多い）介助を行う前に, より援助力の弱 い(少ない) 介助（例えば, “声がけ”や“身振り”な 
表 1 対象入所者のベッドから車椅子への移乗介助における SLP による評価基準

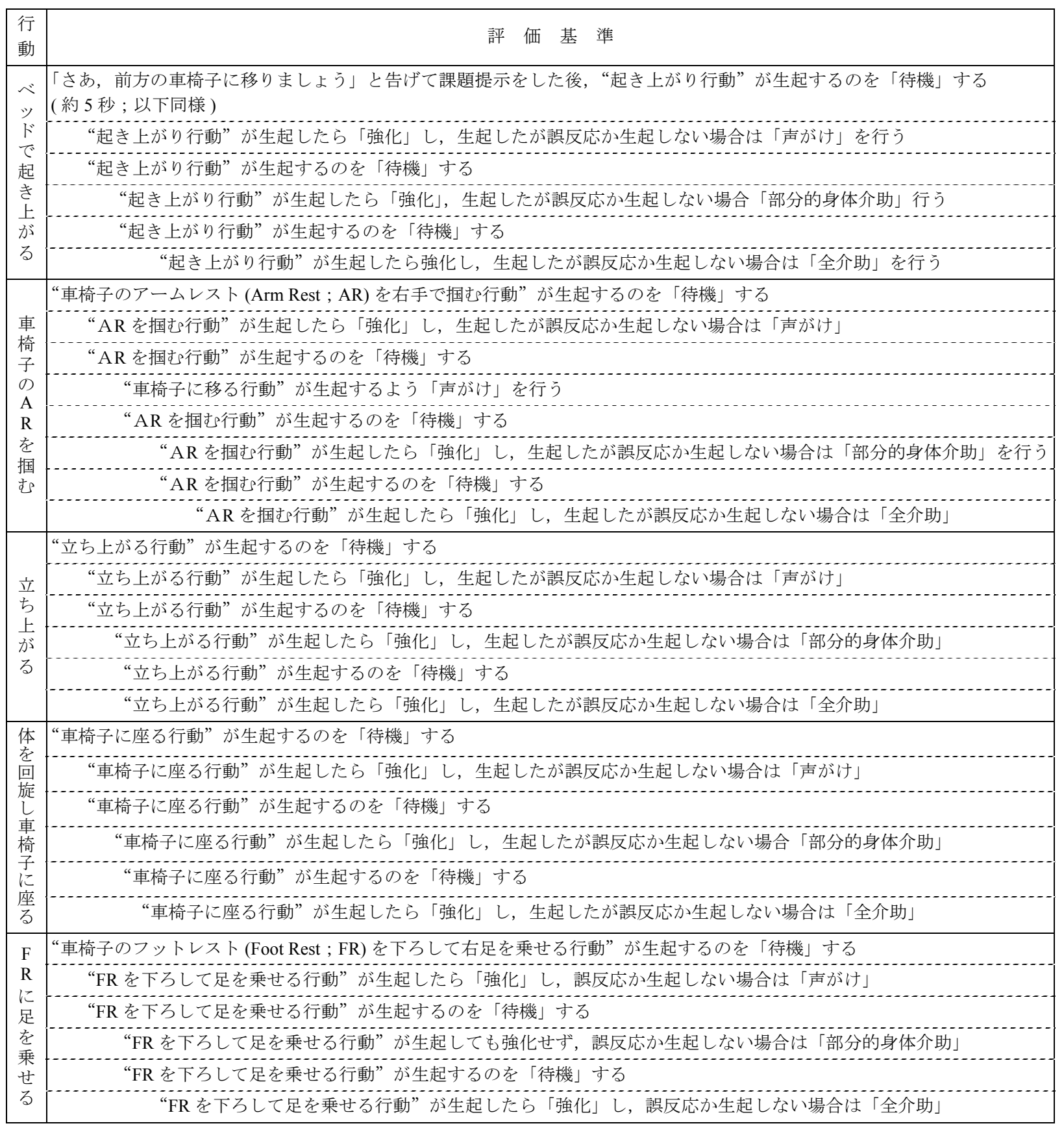

ど）を行い, 援助力の弱い（少ない）援助からより援 助力の強い (多い) 援助へ徐々に移行させることによ り，なるべく弱い(少ない) 援助で対象者の標的とす る行動を生起させることを目的とする応用行動分析学 の援助技法 ${ }^{10)}$ のことをいう。すなわち, (1)ベッド上で 起き上がる，(2)前方の車椅子のアームレストを掴む， (3)車椅子から立ち上がる, (4)身体を回旋させて車椅子
に座る, (5)足をフットレストに乗せる, のように移乗 課題を $5 つ$ 単位行動に分割し，まずは“声がけ”（対 象者に口頭で指示を行うことで単位行動の生起を促す こと）を行って入所者の行動が生起するかどうか一定 時間 “待機”（ある種の介助を行った後，入所者が単位 行動を生起させる余地を十分に与えるため, 次の介助 を提示するのを一定時間 [5秒程度]保留すること）し， 
表2 各対象入所者のベッドから車椅子への移乗課題における各単位行動の遂行レベル

\begin{tabular}{|c|c|c|c|c|c|}
\hline 入所者 & $\begin{array}{l}\text { ベッド上で } \\
\text { 起き上がる }\end{array}$ & $\begin{array}{c}\text { 車椅子のアーム } \\
\text { レストを掴む }\end{array}$ & $\begin{array}{l}\text { 車椅子から } \\
\text { 立ち上がる }\end{array}$ & $\begin{array}{l}\text { 身体を回旋させ } \\
\text { て車椅子に座る }\end{array}$ & $\begin{array}{l}\text { 車椅子のフットレ } \\
\text { ストに足を乗せる }\end{array}$ \\
\hline 入所者 $\mathrm{D}($ 施設 $\mathrm{A})$ & 声がけ & “待機”のみで生起 & 身体ガイド & 身体ガイド & 声がけ \\
\hline 入所者 E(施設 B) & 声がけ & “待機”のみで生起 & 身体ガイド & 身体ガイド & “待機”のみで生起 \\
\hline 入所者 F(施設 C) & 声がけ & “待機”のみで生起 & 身体ガイド & 身体ガイド & “待機”のみで生起 \\
\hline
\end{tabular}

一定時間内に行動生起が起こらなかった場合には次に 援助力の強い介助である“部分的身体介助”（対象者の 身体の一部を保持して単位行動の一部を動かし誘導す ることにより行動の生起を促すこと）を速やかに行い “待機”する。それでも行動生起が起こらなかった場合 には最も援助力の強い介助である “全介助”（対象者の 身体の一部もしくは多くの部分を保持して単位行動の 全てを動かすこと）を速やかに行うという一連の評価 手続きを施行し, 入所者がどのレベルの介助で各単位 行動を遂行したかを, 実際に一名の調査者が各入所者 に日を分けて 3 回ずつ介助を行い, “最も軽度な介助で 各単位行動の遂行が得られたときの介助の種類”を記 録した（表 2)。そして，これら評価場面のビデオ記録 を他の調査者に確認してもらうことで, 評価結果の信 頼性をチェックした。なお, “声がけ”, “部分的身体介 助”, “全介助”, “待機” 等の操作的定義は, 筆者ら ${ }^{11}$ が認知症を有する高齢者施設入所者の車椅子操作評価 に用いた定義を修正したものである。

介護職員に対するデータ収集は, 各施設における各 入所者の居室にて各介護職員が入所者に対しベッドか ら車椅子への移乗介助を行っている機会を利用して3 回〜4回の移乗介助場面を約 3 週間にわたりビデオ記録 し, 以下の処理を行った。すなわち, 1 回の移乗介助機 会を構成する入所者による5つの単位行動の遂行を援 助するため, 介護職員が前述の 3 種類の介助のうちど の介助を何回行ったかをカウントし, それら介助を行 う前に “待機”を行ったかどうかを判定してその回数 をカウントした。また, 入所者が介護職員による前述 の “全介助”を除く 2 種類の介助（“声がけ”, “部分的 身体介助”）によって，もしくは“待機”のみで各単位 行動を完全に遂行した場合, 介護職員が入所者に対し て (1) “賞賛”や“承認”（「はい」「そう」「いいですよ」 など, 入所者が単位行動を完遂した直後に与えられる “注目”を伴うフィードバック), (2) “無反応”(介護職 員が入所者に対し何ら反応を示さないこと), もしくは (3) “中途介助” (“声がけ”, “部分的身体介助”もしくは “待機”のみで入所者が単位行動を生起し, 遂行してい
る最中であるにもかかわらず介護職員が “部分的身体 介助” “全介助” などを行動遂行の途中に行ってし まうこと）のうちどの対応の仕方を何回行ったかを力 ウントした。なお,これら 3 種類の対応については括弧 内に示すように操作的に定義した。以上の処理を 3 力所 の高齢者施設に勤務するすべての対象介護職員につい て施行し, その介助の種類別総数と “待機” の総数, お よび各入所者の移乗課題遂行後における介護職員によ る対応の種類別総数を算出した。

\section{III. 結 果}

少なくとも“声がけ”や“部分的身体介助”レベル の介助で各単位行動を遂行可能な入所者に対し, 3 力所 の介護老人保健施設における 29 名の対象介護職員が施 行した計 260 回の各単位行動に対する介助の $87 \%(226$ 回）で “声がけ”や“部分的身体介助”を行わずに直接 “全介助”が行われていた。また, “全介助”が行われ る前に “部分的身体介助”および“声がけ”が行われ たのは，各々 8\%（21 回）と5\%（13 回）であった。そ して，それらの介助（“声がけ”，“部分的身体介助”お よび “全介助”）を行う前に入所者の各単位行動が生起 するのを “待機”したのは, 260 回の介助のうち4\%(10 回）であった。また，介護職員による “待機”，“声が け”もしくは“部分的身体介助”によって単位行動を 遂行したケースは34回観察されたが，完全に遂行され た直後における介護職員の入所者に対する対応は $82 \%$ （28回）が “無反応”で，“賞賛”や“承認”が与えられ たのは 3\%（1 回）であり，15\%（5 回）の“中途介助” が行われていた。

\section{IV. 考 察}

学習心理学の分野では, “学習”とは「練習や経験に 基づく比較的永続的な行動の変容過程」であると定義 されている12)。現在まで，この“学習”のメカニズム に関するさまざまな理論が提唱されているが, その代 
表的なものの一つが米国の学習心理学者 B.F.Skinnerに より提唱された “才ペラント条件付け理論”である。こ の理論の大きな特徵は, 理論を構成する仮説が動物実 験を柱とする基礎的な実験研究により検証され, 行動 制御に関する普遍的な法則として国際的に認知されて いる5-7)点にある。その第一の法則が “好子出現による 強化”であり,「行動の直後に好子が出現したり, 好子 が増加すると（すなわち，対象がそのような経験をす ると）その行動は将来起こりやすくなる」6) と定義され ている，また，“好子”とは「行動の直後に出現すると， その行動の将来の生起頻度を増加させる刺激, 出来事, 条件」6) と定義されており，一般的に人（特に成人）に おいては賞賛や承認が好子としての機能を有するとさ れている ${ }^{13)}$ 。本調査の結果をこの行動法則に照らして 考えると以下に示すようなメカニズムが機能する可能 性が高くなると考えられる。(a) 介護職員が施行した計 260 回の入所者の単位行動に対する介助の $87 \%$ におい て “声がけ”，“部分的身体介助” など入所者の単位行 動の生起を促す介助を行っておらず, それら介助が施 行される前に “待機” した施行はわずか4\%であった が, このような環境では標的とされる単位行動が生起 し難く, その結果, 好子が与えられる機会が少なくな り標的とされる単位行動の生起頻度が増加し難くなる。 (b) (a) に関連して, すべての入所者が “声がけ”や“部 分的身体介助”もしくは“待機” のみで単位行動を遂 行することが可能なレベルであるにもかかわらず介護 職員による介助の $87 \%$ が “全介助”であったが, 入所 者としてはより楽に単位行動を遂行できることから“全 介助”を提供することが好子として機能し, 入所者の 依存的行動（例えば，“全介助”されるのを待ったり， “全介助”を要求したりする）を増加させてしまう。次 に“消去 (extinction)”と呼ばれる行動法則に照らして 考察する。“消去” は, 定義上次のように表現されてい る。「これまで多少なりとも強化されていた（あるいは 強化された）行動に対して強化の随伴性を中止すると, 強化を受けた以前の状態までその行動は減少する」6)。 すなわち，入所者が “声がけ”や“部分的身体介助”も しくは “待機”のみで単位行動を遂行したケース 34 回 あったが，介護職員の対応の $82 \%$ “無反応”である ことから消去のメカニズムが機能して入所者の標的と される単位行動は減少する傾向となる。また, 入所者 が単位行動を遂行している最中であるのにもかかわら ず “部分的身体介助” ‘ “全介助” が行われ, 単位行動 の遂行を抑止する手続きが $15 \%$ 存在しており，このよ うな対応は自立的な行動の遂行を妨害し, 入所者に賞
賛などの好子が与えられる機会を奪ってしまうことと なる。

この種の先行調査や研究は非常に少ないが, Burgio ら ${ }^{14)}$ は Baltes らが行った施設入所の高齢者との介護職 員とのコミュニケーションにおける相互作用に関する 大規模調査 ${ }^{1)}$ を取り上げ，高齢者自身による整容や更 衣などの遂行は時間がかかりすぎるなどの理由から介 護職員が代わりに行ってしまうことが多い。換言すれ ば，高齢者のセルフケアにおける依存的行動は肯定的 に援助される (強化される) が，一方，自立的な行動 は無視される傾向があることが確認されたとしており， 本調査結果を支持している。そして, 彼らは対応策と して介護職員による入所者への介助や対応方法をより 適切なものに変化させるためのスキルに関するトレー ニングプログラムを発展させることの重要性を指摘し ている1-3,14)。

本調査においては，一部の地域における 3 力所の介 護老人保健施設における介護職員の中から協力者のみ を調查対象としたことから，本調査結果がわが国の介 護老人保健施設における一般的な傾向を示していると 結論づけるのは困難である。しかしながら, 事前観察 にて 3 施設におけるほとんどの介護職員が直接 “全介 助”を行っているという印象を得ていたこと, 学習理 論や行動変容法に関する科目が厚生労働省による新介 護福祉士養成カリキュラムに指定されていないこと, 介護福祉士の資格を有していない者であっても介護職 員として勤務することが現状では可能であること ${ }^{15)}$, さらに, 介護職員に対する教育体制も不十分 ${ }^{16)}$ である ことを考えると, 本調査結果がわが国における介護職 員の移乗介助の実態を反映していると推測することは 可能であると考えられる。

以上, 本調查においては 3 力所の介護老人保健施設 に勤務する介護職員が日頃行っている移乗介助に関し てその具体的な介助や対応の仕方について調查し, “才 ペラント条件付け理論”における代表的な行動法則に 照らして検討した結果, 入所者の依存行動を増加させ, 自立行動を減少させる可能性が高いことが示唆された。 今後は, より大規模かつさまざまな介護職員による日 常生活介助に関する調査が望まれると同時に, 理学療 法士は介護老人保健施設入所者の身体機能の維持・向 上を担う重要な専門職であることから，高齢障害者の 依存行動の増加もしくは自立的行動の減少による廃用 性の機能低下を防ぐべく, Baltes ら 1-3) が指摘するよう な介護職員に対する学習理論を背景とした行動論的な 介助指導や教育にもチャレンジしてゆく必要があろう。 


\section{引用文献}

1) Baltes MM, Burgess RL, Stewart RB: Independence and dependence in self-care behavior in nursing home residents: An operant observational study. International Journal of Behavior Development, 1980, 3: 489-500.

2) Baltes MM, Wahl HW: The behavioral system of dependency in the elderly: Interaction with the social environment. In Ory M, Abeles RP, Lipman PD (Ed): Aging, health, and behavior. Sage Publications, CA, 1991, pp83-106.

3) Baltes MM: Dependency in old age: Gains and losses. Curr Dir Psychol Sci, 1995, 4: 14-19.

4) 博野信次 : 痴呆症患者の日常生活活動の評価と支援. 理学療 法ジャーナル，2000, 34: 313-320.

5) 河嶋 孝, 堀 耕治, 佐藤方哉・他: 行動心理ハンドブッ ク. 培風館, 東京, 1994, pp15-27.

6) Malott RW, Malott ME, 佐藤方哉・他 : 行動分析学入門. 産業 図書, 1998, pp5-86.

7) Mazur JE：メイザーの学習と行動. 磯 博行・他（訳），二 瓶社，大阪，1996, pp109-195.

8) Mathews RM, Altman H: Teaching nurses aides to promote independence in people with dementia. Journal of Clinical Geropsychology, 1997, 3: 149-156.

9) 小林和彦, 園山繁樹, 戸村成男・他 : 老人保健施設における
行動分析学の枠組みを用いた介助技術指導に関する研究— トランスファー介助における効果に関する検討一. 行動療法 研究, 2003, 29, 93-104.

10) Winborn L, Wacker DP, Richman DM, et al.: Assessment of selection for functional communication training packages. J Appl Behav Anal, 2002, 35: 295-298.

11) 小林和彦, 辻下守弘, 鶴見隆正・他 : 老人保健施設での車椅 子操作指導に対する行動分析的アプローチの適用. 理学療法 ジャーナル，2000, 34(2): 135-138.

12) 実森正子, 中島定彦: 学習の心理一行動のメカニズムを探る 一。 サイエンス社, 2000, p2.

13) Pinkston EM, Linsk NL : 高齢者の在宅ケア一家族に対する新 しいアプローチ一. 浅野 仁, 芝野松次郎 (監訳)，ミネル バ書房，京都，1992, pp85-89.

14) Burgio LD, Burgio KL: Behavioral gerontology: Application of behavioral methods to the problems of older adults. J Appl Behav Anal, 1986, 19: 349-355.

15) 厚生労働省: 社会福祉士及び介護福祉士養成課程における教 育内容等の見直し (平成 20 年 4 月) http://www.mhlw.go.jp/ bunya/seikatsuhogo/shakai-kaigo-yousei.html（閲覧日 2010年3月 1日).

16) 厚生労働省 : 介護労働者の確保・定着率に関する研究会一中 間とりまとめ一 (平成20年4月) http: //www-bm.mhlw.go.jp/ shingi/2008/06/txt/s0620-3（閲覧日2010年3月1日）. 